\title{
Isolation by Differential and Zonal Centrifugation of Minicells Segregated by Escherichia coli
}

\author{
By GEOFFREY R. BARKER, CAROLINE S. CORDERY, \\ DEAN JACKSON AND STUART F. J. LE GRICE* \\ Department of Biochemistry, The University, \\ Manchester M13 9PL
}

With an Appendix: Microbiological Surveillance

(Received 10 August 1978)

\begin{abstract}
Minicells segregated from Escherichia coli $\chi 925$ carrying a drug-resistance plasmid were separated from nucleated cells by differential centrifugation and purified by rate-zonal centrifugation in sucrose gradients. Minicells purified in this way were capable of donating the plasmid to nucleated cells. They also incorporated thymidine, uridine and methionine into macromolecules. Methods are described for purification of plasmid-containing minicells on a scale large enough to allow isolation of DNA, DNA polymerase and RNA polymerase in sufficient quantities for studies of enzymes involved in replication and transcription of plasmid DNA.
\end{abstract}

\section{INTRODUCTION}

In connection with studies on the expression of plasmid-borne genes in enterobacteria, it became necessary to prepare relatively large quantities of plasmid DNA, DNA polymerases and RNA polymerases. Plasmid DNA can be separated from chromosomal DNA and characterized by making use of its superhelical nature and its resistance to denaturation or, after transfer into a heterologous recipient, by virtue of the difference in buoyant density between host and plasmid DNA. Using any of these methods, radioactively labelled plasmid DNA is readily characterized on a very small scale although isolation on a preparative scale is more difficult. Isolation of enzymes associated with plasmid replication and transcription also presents difficulties. Not only is it necessary to prepare enzymes in sufficient quantity for purification and assay of activity, but, in addition, there are no clear criteria for the recognition of enzymes specifically associated with the plasmid. Humphreys et al. (1975) have described a method for preparation of large quantities of plasmid DNA by precipitation with polyethylene glycol from cleared lysates of bacteria prepared by the method of Clewell \& Helinski (1969). However, this method is not readily adapted to the isolation of plasmid-associated enzymes.

The discovery that plasmids may segregate into minicells during cell division (Kass \& Yarmolinsky, 1970) offers an alternative method of separating plasmid DNA from chromosomal DNA in minicell-segregating strains. Moreover, it has been shown that both DNA polymerase and RNA polymerase activities are present in plasmid-containing minicells (Hurwitz \& Gold, cited by Cohen et al., 1968a). It has also been demonstrated that such minicells are capable of protein synthesis (Fralick et al., 1969; Levy, 1974; Levy et al., 1974). However, it is probable that only a limited number of enzymes are

* Present address: Department of Molecular Biology, University of Edinburgh, King's Buildings, Mayfield Road, Edinburgh EH9 3JR.

$0022-1287 / 79 / 0000-8314 \$ 02.00$ (C) 1979 SGM 
synthesized. Moreover, the possibility of radioactively labelling enzymes coded for by plasmid genes does not obviate the difficulty of preparing sufficient material for enzymic assays.

Partial separation of minicells from nucleated cells is normally achieved by differential centrifugation (Cohen et al., 1968b). Purification of crude preparations has been carried out by sedimentation in gradients of glycerol (Wickner et al., 1972) or sucrose (Adler et al., 1967; Inselburg, 1970; Reeve et al., 1973). Membrane filtration has also been used, but it is reported that this results in low yields (Frazer \& Curtiss, 1973). To increase the efficiency of the removal of nucleated cells, such cells have been partially destroyed by induction of a lysogenic phage (Kass \& Yarmolinsky, 1970) and by sonication and treatment with penicillin (Khachatourians \& Saunders, 1973). For relatively large-scale preparations, the use of high concentrations of penicillin has been recommended (Levy, 1970) but unexpected effects of ampicillin on the protein-synthesizing capacity of minicells have been recorded (Roozen et al., 1971). Brief reference has been made (Cohen et al., 1968b) to the use of zonal centrifugation for preparation of minicells and it was decided to attempt to develop this method for the present purposes. To achieve high purity of minicell preparations on a large scale, it was necessary to maintain strict control of a number of factors, and the experiments described below define conditions for separation of minicells in a high state of purity from batches up to 201 of culture.

\section{METHODS}

Bacterial strains. The minicell-segregating strain Escherichia coli $\chi 925$ was a gift from Dr R. Curtiss and was derived from strain P678 (for genotype, see Bachmann, 1972). Strain $\chi 925$ was conjugated with $E$. coli J5-3R1 as donor and $E$. coli $\chi 925 \mathrm{R} 1$ was selected using plates containing chloramphenicol $\left(25 \mu \mathrm{g} \mathrm{ml}^{-1}\right)$ but lacking methionine. Escherichia coli $\chi 925 \mathrm{R} 1$ was maintained on nutrient agar slopes and periodically re-selected. The ability of minicells to donate $\mathrm{R} 1$ in conjugation was tested using $E$. coli J5-3 as recipient. Escherichia coli J5-3 and E. coli J5-3R1 were gifts from Dr N. Datta (for genotype, see Meynell \& Datta, 1966).

\section{Initial differential centrifugation of minicells}

Pilot scale. Escherichia coli $\chi 925 \mathrm{R} 1$ was grown at $37^{\circ} \mathrm{C}$ overnight with shaking in $300 \mathrm{ml}$ of L-broth (Lennox, 1955), transferred into 31 of fresh medium and incubated with aeration at $37^{\circ} \mathrm{C}$ for $3 \mathrm{~h}$, at which time $A_{650}$ was approximately $1 \cdot 0$. The culture was centrifuged for $5 \mathrm{~min}$ at $4{ }^{\circ} \mathrm{C}$ in the $6 \times 250 \mathrm{ml}$ head of the MSE High Speed 18 centrifuge at $3000 \mathrm{rev} . \mathrm{min}^{-1}$ and the crude minicells were recovered by centrifugation of the supernatant in the same centrifuge for $15 \mathrm{~min}$ at $10000 \mathrm{rev} \cdot \mathrm{min}^{-1}$. The pellets were resuspended in one-tenth of the original volume of $L$-broth, recentrifuged and stored at $-20^{\circ} \mathrm{C}$.

Large scale. Escherichia coli $\chi 925 \mathrm{R} 1$ was grown to stationary phase at $37^{\circ} \mathrm{C}$ with aeration in 61 of $\mathrm{L}$-broth and then used to inoculate $80 \mathrm{l}$ of L-broth. The culture was grown with vigorous aeration for $15 \mathrm{~h}$ with the addition of polypropylene 750 as antifoaming agent. The fermenter was not sampled and the effluent air was passed through a steam injector before being released into the atmosphere. The cells and minicells were harvested using an Alfa-Laval continuous action centrifuge which was surrounded by a curtain of muslin soaked in sodium hypochlorite solution. The supernatant was collected in 201 vessels plugged with cotton wool and maintained under slightly reduced pressure to prevent dissemination of contaminated aerosol. The total yield of nucleated cells and minicells (approx. $500 \mathrm{~g}$ ) was re-suspended in $4 \mathrm{lof} \mathrm{L}$-broth and centrifuged at $4{ }^{\circ} \mathrm{C}$ for $30 \mathrm{~min}$ in the MSE $6 \mathrm{~L}$ centrifuge at $2000 \mathrm{rev}$. $\mathrm{min}^{-1}$. The opalescent supernatant was centrifuged at $4{ }^{\circ} \mathrm{C}$ for $15 \mathrm{~min}$ in the $6 \times 250 \mathrm{ml}$ head of the MSE High Speed 18 centrifuge at $10000 \mathrm{rev} \cdot \mathrm{min}^{-1}$. The clear supernatant was removed and the pellets (approx. $55 \mathrm{~g}$ ) were stored at $-20^{\circ} \mathrm{C}$.

Purification of minicell preparations by zonal centrifugation. In different experiments, 5 to $20 \%$ and 10 to $30 \%(\mathrm{w} / \mathrm{v})$ sucrose gradients were used. In the following descriptions, quantities shown in square brackets refer to experiments using 10 to $30 \%(\mathrm{w} / \mathrm{v})$ sucrose gradients. Unless indicated in this way, quantities and conditions used in different experiments were identical.

Introduction of gradient solutions into the rotor. A 5 to $20 \%$ [10 to $30 \%](\mathrm{w} / \mathrm{v})$ linear sucrose gradient was introduced into the outer feed-line of the AXII zonal rotor in the MSE 6L centrifuge, at a loading speed of $400 \mathrm{rev}$. $\mathrm{min}^{-1}$, using $675 \mathrm{ml}$ of $5 \%$ [10\%] (w/v) sucrose and $675 \mathrm{ml}$ of $20 \%$ [30\%] (w/v) sucrose, 
both dissolved in 2 mm-sodium phosphate buffer ( $\mathrm{pH} \mathrm{6.8)} \mathrm{containing} 1.0 \mathrm{~mm}-\mathrm{Na}_{2}$ EDTA. The gradient was formed by the method of Ayad et al. (1968) using an LKB Multiperpex pump fitted with three heads and a pumping speed of $75 \mathrm{ml} \mathrm{min}-1$.

Centrifugation of minicells. The pellet containing up to $2.5 \mathrm{~g}[16 \mathrm{~g}]$ of crude wet minicells was suspended in $10 \mathrm{ml}[15 \mathrm{ml}]$ of L-broth and $10 \mathrm{ml}$ [15 ml] of $4 \%$ [10\%] (w/v) sucrose was added slowly with stirring.

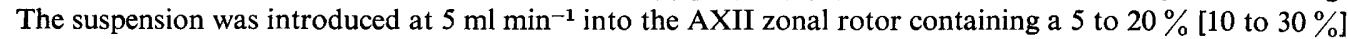
sucrose gradient at a loading speed of $400 \mathrm{rev} \cdot \mathrm{min}^{-1}$. A further $20 \mathrm{ml}[30 \mathrm{ml}]$ of $1 \%$ [2\%] (w/v) sucrose was introduced to displace the cell suspension from the centre of the rotor and the speed of the rotor was then increased to 2000 [2500] rev. $\mathrm{min}^{-1}$ which was maintained until the opalescence extended nearly to the outer edge of the rotor (approx. $50 \mathrm{~min}$ ). The rotor speed was then reduced to $400 \mathrm{rev} . \mathrm{min}^{-1} \mathrm{and} 10 \mathrm{ml}$ fractions were pumped from the rotor at the rate of $10 \mathrm{ml} \mathrm{min}^{-1}$ by introducing $40 \%[50 \%](\mathrm{w} / \mathrm{v})$ sucrose into the outer feed-line. Samples were taken for measurement of $A_{650}$ and refractive index. Fractions containing minicells were pooled and harvested by centrifugation at $10000 \mathrm{rev} \cdot \mathrm{min}^{-1}$ in the MSE High Speed 18 centrifuge. The pellet was resuspended in $100 \mathrm{ml}$ of $0.9 \%(\mathrm{w} / \mathrm{v}) \mathrm{NaCl}$, centrifuged again under the above conditions and stored at $-20^{\circ} \mathrm{C}$.

\section{Assessment of purity and physiological activities of minicells.}

Measurements of numbers of whole cells and minicells. Samples of purified minicells were suspended in $0.9 \%(\mathrm{w} / \mathrm{v}) \mathrm{NaCl}$ and serially diluted to give suitable concentrations for measurement of viable nucleated cells by plating on nutrient agar and incubation at $37^{\circ} \mathrm{C}$, and of total cell concentration using the Coulter counter model $Z_{\mathrm{B}}$ fitted with a $30 \mu \mathrm{m}$ orifice.

Conjugation. Purified minicells prepared from $E$. coli $\chi 925 \mathrm{R} 1$ were conjugated with $E$. coli $\mathrm{J} 5-3$ as recipient, following the method of de Haan \& Gross (1962) except that L-broth was used as the medium, the ratio of minicells to recipient cells was approximately $1: 4$ and the mixed cultures were shaken at 20 strokes $\mathrm{min}^{-1}$. The number of recombinants was determined by plating on minimal agar containing chloramphenicol $\left(25 \mu \mathrm{g} \mathrm{ml}^{-1}\right)$. The frequency of transfer of the $\mathrm{R}$ factor was calculated as (no. of $\mathrm{R}^{+}$ recipient cells)/(initial no. of $\mathrm{R}^{+}$donor minicells).

Capacity for synthesis of DNA, RNA and protein. Synthesis of DNA was measured by incubating suspensions of purified minicells at $37{ }^{\circ} \mathrm{C}$ in L-broth supplemented with $0 \cdot 1 \%(\mathrm{w} / \mathrm{v})$ glucose, at a minicell density to give $A_{650} 0 \cdot 2$, with $\left[{ }^{3} \mathrm{H}\right.$ ] thymidine $\left(15 \mu \mathrm{Ci} \mathrm{ml}{ }^{-1}\right)$. Samples $(100 \mu \mathrm{l})$ were transferred at intervals to discs of Whatman $3 \mathrm{MM}$ filter paper, dried, washed twice with $5 \%(\mathrm{w} / \mathrm{v})$ trichloroacetic acid containing 2 mM-sodium pyrophosphate, three times with $95 \%(v / v)$ ethanol, once with ethanol/ether $(1: 1, \mathrm{v} / \mathrm{v})$ once with ether and dried. Synthesis of RNA was measured similarly except that the incubation medium was also supplemented with deoxyadenosine $\left(250 \mu \mathrm{g} \mathrm{ml}^{-1}\right)$ following Boyce \& Setlow (1962) and [ $\left.{ }^{3} \mathrm{H}\right]$ uridine $\left(15 \mu \mathrm{Ci} \mathrm{ml}{ }^{-1}\right)$ replaced $\left[{ }^{3} \mathrm{H}\right]$ thymidine. For measurement of the synthesis of protein, minicells were suspended at the same density as above in the methionine assay medium of Levy (1974) and incubated at $37^{\circ} \mathrm{C}$ for $2 \mathrm{~h}$ with $\left[{ }^{35} \mathrm{~S}\right]$ methionine $\left(75 \mu \mathrm{Ci} \mathrm{ml}{ }^{-1}\right)$. The suspension was lysed as described below and the lysate was chromatographed on a column $(80 \times 2 \mathrm{~cm})$ of Sephadex G-75. Samples $(25 \mu \mathrm{l})$ were transferred to filter paper discs and dried.

Radioactivity on filter paper discs in each of the above experiments was measured with the Packard TriCarb model 3385 liquid scintillation spectrometer using automatic pre-selected settings and toluene containing $0 \cdot 1 \%(\mathrm{w} / \mathrm{v})$ 1,4-bis-2-(4-methyl-5-phenyloxazolyl)benzene and $0 \cdot 4 \%(\mathrm{w} / \mathrm{v})$ 2,5-diphenyloxazole as scintillator.

\section{Isolation and examination of components from minicells carrying plasmid R1.}

Isolation of DNA. A pellet of purified minicells $(4.0 \mathrm{~g})$ was quickly thawed and lysed, essentially following the method of Godson \& Sinsheimer (1967). After incubation with Brij 58 and adjustment of the concentration of $\mathrm{MgSO}_{4}$ to $10 \mathrm{~mm}$, the suspension was frozen and thawed three times and then incubated at $37^{\circ} \mathrm{C}$ for $4 \mathrm{~h}$ with pronase (final concentration $250 \mu \mathrm{g} \mathrm{ml}^{-1}$ ). Cell debris was removed by centrifugation at $25000 \mathrm{rev} . \mathrm{min}^{-1}$ for $20 \mathrm{~min}$ and a sample of the supernatant was analysed for DNA by the method of El-Hamalawi et al. (1975) using native calf thymus DNA as standard. The rest of the supernatant was loaded by pumping upwards at $10 \mathrm{ml} \mathrm{h}^{-1}$ on to a column of Sepharose $2 \mathrm{~B}$ equilibrated with $0 \cdot 1 \mathrm{M}-\mathrm{Tris} / \mathrm{HCl}$ buffer, $\mathrm{pH} 7 \cdot 4$, containing $10 \mathrm{~mm}$-EDTA and $0 \cdot 2 \%(\mathrm{w} / \mathrm{v})$ sodium azide. The column was eluted with the same buffer and fractions $(1 \mathrm{ml})$ having high $A_{\mathbf{2 6 0}}$ were pooled and stored at $4{ }^{\circ} \mathrm{C}$.

Equilibrium centrifugation of DNA in caesium chloride. A sample (approx. $3 \mathrm{ml}$ ) of a lysate of purified minicells was applied, either directly or after appropriate treatment, to a solution of $\mathrm{CsCl}$ in $0.05 \mathrm{M}-\mathrm{Tris} /$ $\mathrm{HCl}$ buffer, pH 7.0, containing $5 \mathrm{mM}$-EDTA and $5 \mathrm{mM}-\mathrm{MgCl}_{2}$, adjusted to give a refractive index of 1.4000; in experiments requiring it, ethidium bromide $\left(100 \mu \mathrm{g} \mathrm{ml}^{-1}\right)$ was added and the refractive index was adjusted to 1.3910. Solutions were centrifuged for $42 \mathrm{~h}$ at $25^{\circ} \mathrm{C}$ and $42000 \mathrm{rev}$. $\mathrm{min}^{-1}$ in the Ti50 rotor 
of the Beckman L2-65B centrifuge. The gradient was fractionated into 4-drop fractions. Samples were taken for measurement of refractive index, and fractions were diluted with $200 \mu$ l of the above buffer and $A_{260}$ was measured.

Partial purification of DNA polymerase. A pellet of purified minicells $(5 \mathrm{~g})$ was lysed as described above but was not subjected to freezing and thawing. The lysate was sonicated using the Kerry Ultrasonic Generator [Kerrys (Ultrasonics) Ltd, Basildon, Essex] in three $30 \mathrm{~s}$ bursts with periods of cooling for

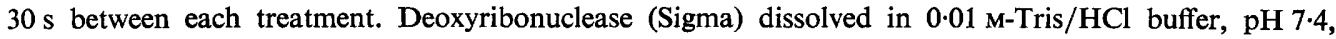
was added to give a final concentration of $20 \mu \mathrm{g} \mathrm{ml}^{-1}$ and the suspension was incubated at $25^{\circ} \mathrm{C}$ until the viscosity showed a marked reduction (approx. $15 \mathrm{~min}$ ). The suspension was then centrifuged for $20 \mathrm{~min}$ at $4^{\circ} \mathrm{C}$ and $18000 \mathrm{rev} . \mathrm{min}^{-1}$ in the type 40 rotor of the Beckman L2-65B centrifuge. The pale yellow supernatant was decanted and, after dialysis overnight at $4{ }^{\circ} \mathrm{C}$ against 5 vol. of $0.02 \mathrm{M}-\mathrm{Tris} / \mathrm{HCl}$ buffer, pH 7.6, containing $1.0 \mathrm{~mm}$-EDTA, $0.5 \mathrm{~mm}$-dithiothreitol and $0.1 \mathrm{M}-\mathrm{NaCl}$, was centrifuged for $90 \mathrm{~min}$ at $4{ }^{\circ} \mathrm{C}$ and $38000 \mathrm{rev} . \mathrm{min}^{-1}$ in the same rotor as above. The supernatant was decanted and dialysed as described above except that the buffer contained, in addition, $10 \%(\mathrm{v} / \mathrm{v})$ glycerol and phenylmethanesulphonyl fluoride $\left(6 \mu \mathrm{g} \mathrm{ml}^{-1}\right)$. The solution was then loaded at a rate of $7 \mathrm{ml} \mathrm{h}^{-1}$ on to a column $(70 \times 8 \mathrm{~mm})$ containing DNA-cellulose prepared by the method of Potuzak \& Wintersberger (1976). The column was eluted with similar buffer but containing stepwise increasing concentrations of $\mathrm{NaCl}$. Fractions (1 ml) were examined for DNA polymerase activity by the method of Setlow (1974).

Partial purification of $R N A$ polymerase. A pellet $(10 \mathrm{~g})$ of purified minicells was lysed as described above for the isolation of DNA polymerase. The extract was then fractionated and assayed for RNA polymerase activity by the method of Burgess (1969) using DEAE-cellulose chromatography and centrifugation in a glycerol gradient. During precipitation with ammonium sulphate, a pellicle formed on the surface of the solution. With smaller quantities of minicells, it was advantageous to avoid this difficulty by removing Brij 58 by passage through Sephadex G-75 and omitting precipitation with ammonium sulphate. Enzymically active material was recovered from the glycerol gradient and examined by polyacrylamide gel electrophoresis as described by Burgess (1969).

\section{RESULTS}

\section{Purification of minicells by rate-zonal centrifugation}

Centrifugation in 5 to $20 \%$ sucrose gradients. Figure $1(a)$ shows the result of rate-zonal centrifugation in a 5 to $20 \%(\mathrm{w} / \mathrm{v})$ sucrose gradient of $1 \mathrm{~g}$ of crude minicells prepared by differential centrifugation of a 31 culture of $E$. coli $\chi 925 \mathrm{R} 1$. Recentrifugation, under the same conditions, of the main minicell-containing fraction (fraction A) gave the result shown in Fig. 1(b), indicating that fraction A contains essentially pure minicells. Recentrifugation of the material from fraction B (Fig. 1a) yielded only a small further quantity of minicells and this was not routinely carried out.

Minicells purified by one rate-zonal centrifugation (fraction A, Fig. $1 a$ ) had a ratio nucleated cells:minicells of approximately $1: 10^{4}$. Minicells purified by two rounds of rate-zonal centrifugation (fraction $\mathrm{C}$, Fig. $1 \mathrm{~b}$ ) gave a ratio nucleated cells:minicells of approximately $1: 6 \times 10^{8}$. Purity in these ranges was obtained using up to approximately $2.5 \mathrm{~g}$ of crude minicells from multiple 31 cultures.

Centrifugation in 10 to $30 \%$ sucrose gradients. Figure 2(a) shows the result of rate-zonal centrifugation on a 10 to $30 \%(\mathrm{w} / \mathrm{v})$ sucrose gradient of $11 \mathrm{~g}$ of crude minicells from 201 of culture of $E$. coli $\chi 925 \mathrm{R} 1$. Recentrifugation, under the same conditions, of material recovered from fraction D gave the result shown in Fig. 2(b). Recovery of the material from fraction $\mathrm{F}$ (Fig. $2 b$ ) gave approximately $4 \mathrm{~g}$ of minicells having a ratio nucleated cells: minicells of $1: 3 \times 10^{8}$. Recentrifugation, under the same conditions, of material from fraction E (Fig. $2 a$ ) gave a similar result to that shown in Fig. 2(b) and gave approximately $3 \mathrm{~g}$ of minicells having a ratio nucleated cells: minicells of $1: 10^{8}$.

\section{Physiological activity of purified minicells}

The transfer frequency of the plasmid from purified minicells from fraction $\mathrm{C}$ (Fig. $1 b$ ) to the $\mathrm{R}^{-}$recipient was $3 \times 10^{-5}$.

The incorporation of $\left[{ }^{3} \mathrm{H}\right]$ thymidine into acid-insoluble material in purified minicells 


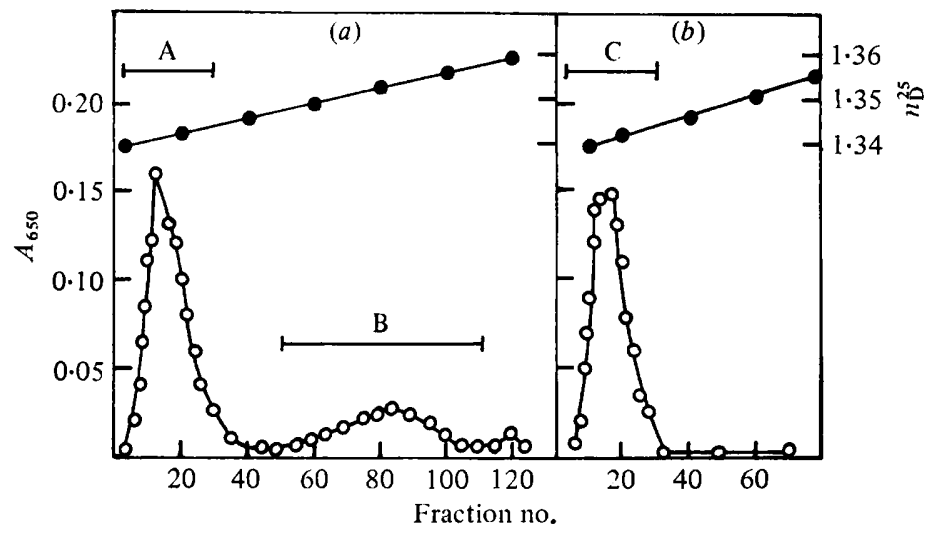

Fig. 1. Purification of minicells derived from Escherichia coli $\chi 925 \mathrm{R} 1$. (a) Crude minicells, prepared by differential centrifugation, submitted to rate-zonal centrifugation in 5 to $20 \%(\mathrm{w} / \mathrm{v})$ sucrose gradient. (b) Recentrifugation, under the same conditions, of minicells recovered from fraction A (see $a$ ). $\bigcirc, A_{650} ; 0$, refractive index $n_{\mathrm{D}}^{25}$.
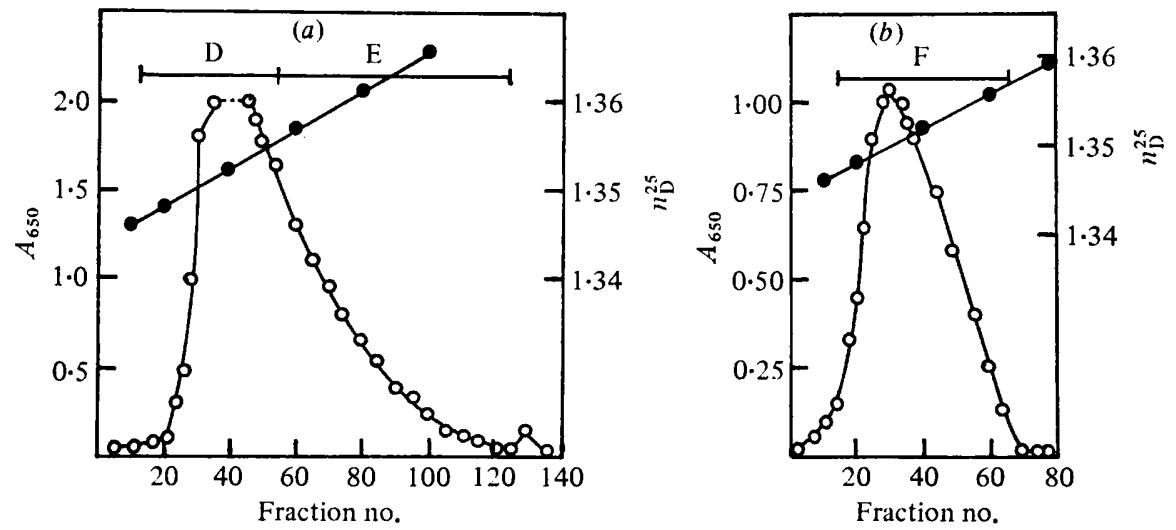

Fig. 2. Purification of minicells derived from Escherichia coli $\chi 925 R 1$. (a) Crude minicells, prepared by differential centrifugation, submitted to rate-zonal centrifugation in a 10 to $30 \%(\mathrm{w} / \mathrm{v})$ sucrose gradient. (b) Recentrifugation, under the same conditions, of minicells recovered from fraction D (see $a$ ). $\bigcirc, A_{650}$; refractive index $n_{\mathrm{D}}^{25}$.

from fraction $\mathrm{C}$ (Fig. $1 b$ ) is shown in Fig. 3(a) and demonstrates the ability of $\mathrm{R}^{+}$minicells to synthesize DNA. Incorporation of $\left[{ }^{3} \mathrm{H}\right]$ uridine into acid-insoluble material by the same minicell preparation, shown in Fig. 3(a), indicates the extent of RNA synthesis. Figure $3(b)$ shows the incorporation of $\left[{ }^{35} \mathrm{~S}\right]$ methionine by purified minicells into material having a molecular weight not less than the exclusion value for Sephadex G-75.

\section{Characterization of DNA}

Fluorometric analysis of a sample of lysate prepared from purified minicells derived from $E$. coli $\chi 925 \mathrm{R} 1$ indicated the presence of $135 \pm 18 \mu \mathrm{g}$ DNA per $\mathrm{g}$ of purified minicells. It is estimated that approximately half of the minicells in purified preparations contain a plasmid. Further experiments would be required to ascertain whether there is a relationship between the proportion of minicells carrying a plasmid and the presence of the $\min A$ and $\min B$ markers, both of which occur in the strain used in the present experiments.

Figure 4 shows the result obtained by chromatography of the lysate of $4 \mathrm{~g}$ of purified minicells on Sepharose 2B. The excluded material (fraction I) consisted essentially of high molecular weight DNA and contained $43 \mu \mathrm{g} \mathrm{DNA} \mathrm{ml}^{-1}$ and $0.5 \mu \mathrm{g}$ protein $\mathrm{ml}^{-1}$. The 

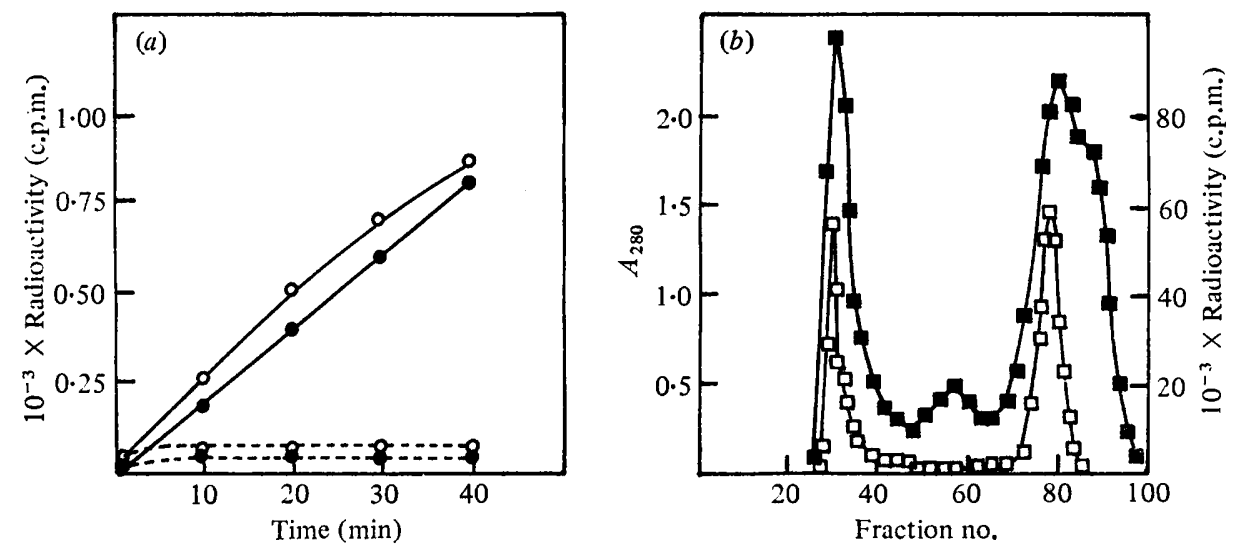

Fig. 3. Physiological activity of minicells derived from Escherichia coli $\chi 925 \mathrm{R} 1$. (a) Incorporation of $\left[{ }^{3} \mathrm{H}\right]$ thymidine $(\mathrm{O}-\mathrm{O})$ and $\left[{ }^{3} \mathrm{H}\right]$ uridine $\left(\mathrm{O}_{-}\right)$into acid-insoluble material. Results obtained using minicells derived from $\mathrm{R}^{-}$E. coli $\chi 925$ are shown by the dashed lines. (b) Chromatography on Sephadex G-75 of material labelled by incubating minicells derived from $E$. coli $\chi 925 \mathrm{R} 1$ with $\left[{ }^{35}\right.$ S]methionine: $\square,{ }^{35} \mathrm{~S}$ radioactivity (c.p.m.); $\mathbf{\square}, A_{280}$.

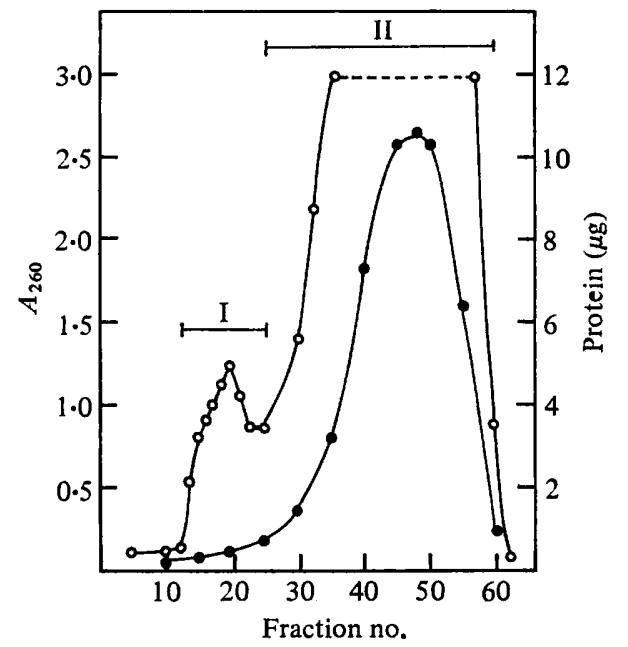

Fig. 4. Chromatography on Sepharose 2B of DNA from minicells derived from Escherichia coli $\chi 925 \mathrm{R} 1$. $O, A_{260} ; 0$, protein $(\mu \mathrm{g})$.

included material (fraction II) contained the major part of the protein present in the lysate together with degraded DNA. The result of equilibrium centrifugation in $\mathrm{CsCl}$ of materials from fraction I (Fig. 4), shown in Fig. 5(a), indicates the presence of a single component having a buoyant density of $1.712 \mathrm{~g} \mathrm{~cm}^{-3}$. A sample of DNA prepared from the plasmidfree strain, $E$. coli $\chi 925$, had the same buoyant density. Centrifugation of a sample of minicell DNA from fraction I (Fig. 4) which had been brought to $\mathrm{pH} 12 \cdot 3$, allowed to stand for $10 \mathrm{~min}$ and brought back to $\mathrm{pH} 7 \cdot 0$, also showed a single band having the same buoyant density. Equilibrium centrifugation of minicell DNA from fraction I (Fig. 4) in $\mathrm{CsCl}$ containing ethidium bromide showed a single band having a buoyant density of $1.635 \mathrm{~g} \mathrm{~cm}^{-3}$ (Fig. $5 b$ ); under similar conditions, DNA isolated from plasmid-free $E$. coli $\chi 925$ gave a single band having a buoyant density of $1.617 \mathrm{~g} \mathrm{~cm}^{-3}$. 

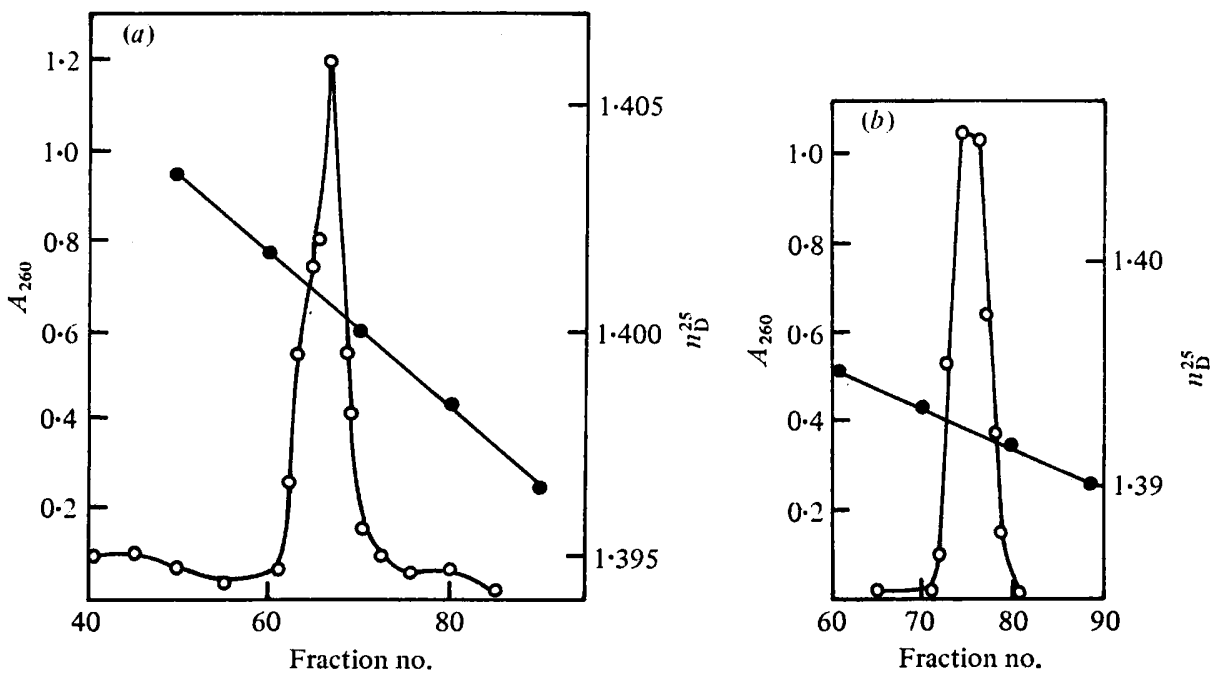

Fig. 5. Equilibrium sedimentation of DNA in fraction I from Fig. 4. (a) Sedimentation in neutral $\mathrm{CsCl}$. (b) Sedimentation in $\mathrm{CsCl}$ containing ethidium bromide. $\bigcirc, A_{260} ; 0$, refractive index $n_{\mathrm{D}}^{25}$.

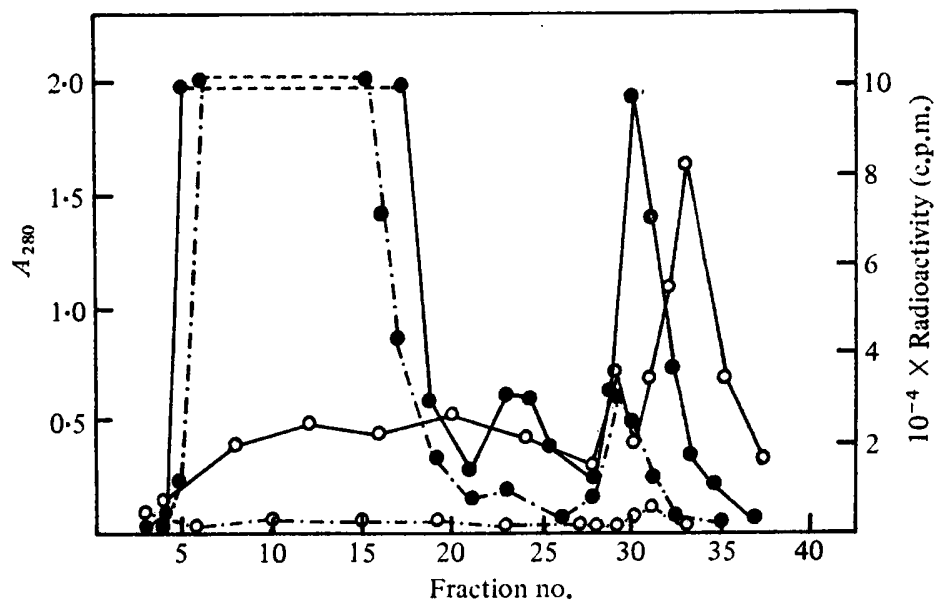

Fig. 6. Chromatography on DNA-cellulose of DNA polymerase from minicells derived from Escherichia coli $\chi 925 \mathrm{R} 1(-)$ and $E$. coli $\chi 925(-\cdot--)$. $\bigcirc,{ }^{3} \mathrm{H}$ incorporated from dATP (c.p.m.); O, $A_{280}$.

\section{DNA polymerase}

Chromatography of a lysate of purified minicells on DNA-cellulose (Fig. 6) showed the presence of DNA polymerase. Chromatography, under the same conditions, of a lysate of plasmid-free $E$. coli $\chi 925$ is also shown.

\section{RNA polymerase}

Figure 7(a) shows the result of chromatography of RNA polymerase from $E$. coli $\chi 925 \mathrm{R} 1$ on DEAE-cellulose. Fractions 37 to 41 were pooled and centrifuged on a 10 to $30 \%(\mathrm{v} / \mathrm{v})$ glycerol gradient yielding an enzymically active fraction as shown in Fig. $7(b)$. RNA polymerase was recovered from fractions 10 to 16 (Fig. $7 b$ ) and subjected to polyacrylamide gel electrophoresis which showed the presence of all four subunits. 

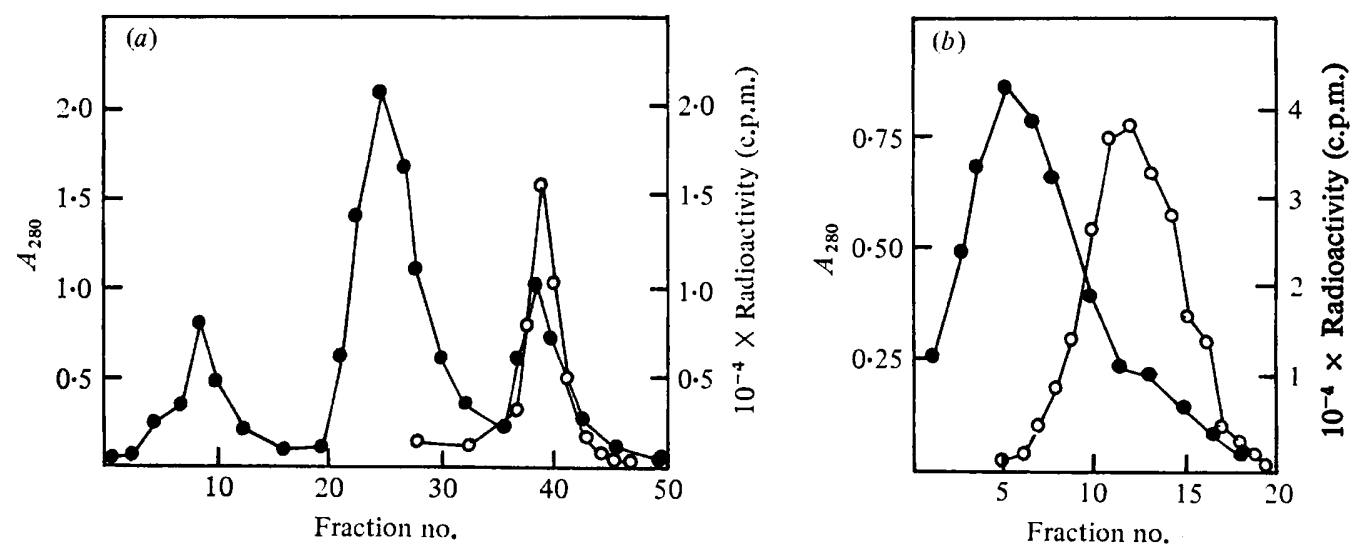

Fig. 7. Partial purification of RNA polymerase from minicells derived from Escherichia coli $\chi 925 \mathrm{R} 1$. (a) Chromatography on DEAE-cellulose. (b) Centrifugation on a glycerol gradient. $\bigcirc$, ${ }^{3} \mathrm{H}$ incorporated from UTP (c.p.m.);,$A_{280}$.

\section{DISCUSSION}

The purpose of the present investigation was to establish a convenient method of preparing minicells segregated from plasmid-bearing $E$. coli to allow isolation of plasmid DNA and associated DNA polymerase and RNA polymerase activities in relatively large quantities. In the experiments described, it was found that purification of minicells by rate-zonal centrifugation is more convenient than the use of multiple tube gradients. For some purposes, adequate resolution of minicells from nucleated cells is obtained by one ratezonal centrifugation in a 5 to $20 \%(\mathrm{w} / \mathrm{v})$ sucrose gradient, but higher purity is attained by a second centrifugation. Rate-zonal centrifugation in 10 to $30 \%(\mathrm{w} / \mathrm{v})$ sucrose gradients is necessary for purification of larger quantities of minicells and precautions are necessary to achieve acceptable resolution.

Nucleated cells of E. coli are more sensitive to lysis by freezing and thawing and by osmotic shock than are minicells. It is necessary to avoid such lysis of nucleated cells during preparation of material for centrifugation because of the effect of high viscosity on the stability of the sample zone during centrifugation. Resolution is critically affected by the volume of suspension introduced into the rotor and this is of particular importance in the purification of large quantities of material. It is recommended that, for pellets of crude minicells weighing up to $16 \mathrm{~g}$, the volume of suspension should not exceed $30 \mathrm{ml}$; for pellets weighing $8 \mathrm{~g}$ or less the volume can be reduced to $20 \mathrm{ml}$. The precautions are necessitated because fractions containing pure minicells traverse only a short distance through the gradient and it is also important to ensure that the minicells occupy a linear part of the gradient. The method described for introducing gradients into the rotor gives satisfactory linear gradients, but steps in the gradient are produced during loading of the sample and the overlay solution, which is required to move the sample into a region of higher centrifugal field. This disturbs the gradients in the region where resolution of minicells and nucleated cells takes place. Experiments indicated that, under the conditions described, a stable linear gradient is set up in the region corresponding to fraction 10 and remains stable until approximately fraction 120 . Similar results are obtained with 5 to $20 \%$ and 10 to $30 \%$ sucrose gradients, but in the latter case, the steps are greater. Unavoidable loss of resolution during centrifugation occurs as a result of broadening of bands due to diffusion. This effect is seen in Fig. 1(a) showing the broader band of whole cells compared with the narrow band of minicells. Thus it is advisable to keep the time of centrifugation as short as possible and this emphasizes the importance of ensuring that the gradient is linear as near the centre of the rotor as possible. 
Using the conditions described, it is recommended that rate-zonal centrifugation in a 5 to $20 \%(\mathrm{w} / \mathrm{v})$ sucrose gradient is used for purification of up to $2.5 \mathrm{~g}$ of crude minicells. For purification of more than $2.5 \mathrm{~g}$ of crude minicells, the use of a 10 to $30 \%(\mathrm{w} / \mathrm{v})$ sucrose gradient is recommended and this has been found to be satisfactory for up to $16 \mathrm{~g}$ of crude minicells. Recentrifugation of material from the first gradient is necessary to achieve acceptable purity.

Escherichia coli minicells prepared by these methods were physiologically active. Minicells carrying the plasmid R1 were capable of transferring the $\mathrm{R}$ factor during conjugation with a frequency in the range normally observed with established cultures of $\mathrm{R}^{+}$donors. In addition to their ability to act as donors in conjugation, the minicells were capable of incorporating thymidine, uridine and methionine into macromolecules. The minicells used in these experiments were contaminated with not more than one nucleated cell per $6 \times 10^{8}$ minicells and it is considered that neither the frequency of transfer nor the incorporation of labelled materials could be attributed to nucleated cells present.

Purified minicells yielded high molecular weight DNA exhibiting properties characteristic of superhelical DNA both as regards its interaction with ethidium bromide and its resistance to denaturation. It also had the same buoyant density as DNA prepared from the host cells from which the minicells had segregated. It is estimated that in the experiments described, open circular and linear DNA amounted to not more than $5 \%$ of the material isolated from purified minicells. The isolation of partially purified DNA polymerase and RNA polymerase from minicell lysates indicates that the methods described give material in sufficient quantity and activity for detailed studies of both DNA and RNA synthesis based on plasmid DNA. The observation that minicells purified by the procedures used are physiologically active suggests that the techniques reported here are suitable for other investigations concerned with bacterial plasmids.

We are indebted to I.C.I. Pharmaceuticals Division for making facilities available for the growth of large cultures and to Dr R. Curtiss and Dr N. Datta for the gift of bacterial cultures. C.S.C. is grateful to S.R.C. and D.A.J. and S.F.J. Le G. to M.R.C. for the award of postgraduate studentships.

\section{REFERENCES}

Adler, H. I., Fisher, W. D., Cohen, A. \& HardiGREE, A. A. (1967). Miniature Escherichia coli cells deficient in DNA. Proceedings of the National Academy of Sciences of the United States of America 57, 321-326.

Ayad, S. R., Bonsall, R. W. \& Hunt, S. (1968). A simple method for the production of accurate linear gradients using a constant-speed peristaltic pump. Analytical Biochemistry 22, 533-535.

Bachmann, B. J. (1972). Pedigrees of some mutant strains of Escherichia coli K-12, Bacteriological Reviews 36, 525-557.

Boyce, R. P. \& Setlow, R. B. (1962). A simple method of increasing the incorporation of thymidine into the deoxyribonucleic acid of Escherichia coli. Biochimica et biophysica acta 61, 618-620.

Burgess, R. R. (1969). A new method for the large scale purification of Escherichia coli deoxyribonucleic acid-dependent ribonucleic acid polymerase. Journal of Biological Chemistry 244, 6160-6167.

Clewell, D. B. \& Helinski, D. R. (1969). Supercoiled circular DNA-protein complex in Escheri- chia coli: purification and induced conversion to an open circular DNA form. Proceedings of the National Academy of Sciences of the United States of America 62, 1159-1166.

Cohen, A., Fisher, W. D., Curtiss III, R. \& ADLER, H. I. $(1968 a)$. The properties of DNA transferred to minicells during conjugation. Cold Spring Harbor Symposia on Quantitative Biology 33, 635-641.

Cohen, A., Fisher, W. D., Curtiss III, R. \& ADLER, H. I. (1968b). DNA isolated from Escherichia coli minicells mated with $\mathrm{F}^{+}$cells. Proceedings of the National Academy of Sciences of the United States of America 61, 61-68.

El-Hamalawi, A.-R. A., Thompson, J. S. \& BARKer, G. R. (1975). The fluorometric determination of nucleic acids in pea seeds by use of ethidium bromide complexes. Analytical Biochemistry 67, 384-391.

Fralick, J. A., Fisher, W. D. \& AdLer, H. I. (1969). Polyuridylic acid-directed phenylalanine incorporation in minicell extracts. Journal of Bacteriology 99, 621-622.

Frazer, A. C. \& CURTISs III, R. (1973). Derepression 
of anthranilate synthetase in purified minicells of Escherichia coli containing the Col-trp plasmid. Journal of Bacteriology 115, 615-622.

Godson, G. N. \& Sinsheimer, R. L. (1967). Lysis of Escherichia coli with a neutral detergent. Biochimica et biophysica acta 149, 476-488.

DE HaAN, P. G. \& Gross, J. D. (1962). Transfer delay and chromosome withdrawal during conjugation in Escherichia coli. Genetical Research 3, 251-272.

Humphreys, G. O., Willshaw, G. A. \& Anderson, E. S. (1975). A simple method for the preparation of large quantities of pure plasmid DNA. Biochimica et biophysica acta 383, 457-463.

INSELBURG, J. (1970). Segregation into and replication of plasmid deoxyribonucleic acid in chromosomeless segregants of Escherichia coli. Journal of Bacteriology 102, 642-647.

Kass, L. R. \& Yarmolinsky, M. B. (1970). Segregation of functional sex factor into minicells. Proceedings of the National Academy of Sciences of the United States of America 66, 815-822.

Khachatourians, G. G. \& Saunders, C. A. (1973). A new method for the preparation of minicells for physiological studies. Preparative Biochemistry 3, 291-298.

LENNOX, E. S. (1955). Transduction of linked genetic characters of the host by bacteriophage P1. Virology 1, 190-206.

LeVY, S. B. (1970). Resistance of minicells to penicillin lysis: a method of obtaining large quantities of purified minicells. Journal of Bacteriology 103, 836-839.
LEVY, S. B. (1974). R factor proteins synthesized in Escherichia coli minicells: incorporation studies with different $\mathbf{R}$ factors and detection of deoxyribonucleic acid-binding proteins. Journal of Bacteriology 120, 1451-1463.

Levy, S. B., McMurry, L. \& Palmer, E. (1974). $\mathrm{R}$ factor proteins synthesized in Escherichia coli minicells: membrane-associated $\mathbf{R}$ factor proteins. Journal of Bacteriology 120, 1464-1471.

Meynell, E. \& DatTA, N. (1966). The relation of resistance transfer factors to the F-factor (sexfactor) of Escherichia coli K12. Genetical Research 7, 134-140.

Potuzak, H. \& Wintersberger, U. (1976). DNA covalently linked to carboxymethylcellulose and its application in affinity chromatography. FEBS Letters 63, 167-171.

Reeve, J. N., Mendelson, N. H., Coyne, S. I., Hallock, L. L. \& Cole, R. M. (1973). Minicells of Bacillus subtilis. Journal of Bacteriology 114, 860-873.

Roozen, K. J., Fenwick, JR, R. G. \& Curtiss III, R. (1971). Synthesis of ribonucleic acid and protein in plasmid-containing minicells of Escherichia coli K-12. Journal of Bacteriology 107, 21-33.

SetLow, P. (1974). DNA polymerase I from Escherichia coli. Methods in Enzymology 29, 3-12.

Wickner, R. B., GinsberG, B., Berkower, I. \& Hurwitz, J. (1972). Deoxyribonucleic acid polymerase II of Escherichia coli I. The purification and characterization of the enzyme. Journal of Biological Chemistry 247, 489-497.

\title{
Appendix: Microbiological Surveillance
}

\author{
By ANN F. TUXFORD, JILL K. HOGG AND \\ THOMAS S. L. BESWICK \\ Department of Bacteriology and Virology, The University, \\ Stopford Building, Oxford Road, Manchester M13 9PT
}

\section{INTRODUCTION}

Concern has been expressed that in vivo plasmid transfer may occur during the course of genetic experiments (Anderson, 1975). Hartley et al. (1976) were unable to demonstrate transference of $\mathrm{R}$ plasmids to the faecal bacterial flora of laboratory workers working with them.

The faecal bacterial flora of one of the authors of the main paper (G.R.B.), who was involved in every stage of the work, was monitored for a prolonged period, not only during his experiments involving Escherichia coli containing a drug-resistance plasmid, but also during intervals preceding and following the six periods each of 2 to $3 \mathrm{~d}$ in which he was engaged on experimental work.

\section{METHODS}

Samples $(1 \mathrm{~g})$ of faecal specimens were homogenized and suspended in nutrient broth. Using the Miles \& Misra technique, triplicate samples from each dilution (up to $10^{-9}$ ) were cultured on electrolyte deficient agar (CLED agar; Oxoid) which contained ampicillin $\left(25 \mu \mathrm{g} \mathrm{ml}^{-1}\right)$, chloramphenicol $\left(10 \mu \mathrm{g} \mathrm{ml}^{-1}\right)$, kanamycin $\left(5 \mu \mathrm{g} \mathrm{ml}^{-1}\right)$ and neomycin $\left(5 \mu \mathrm{g} \mathrm{ml}^{-1}\right)$, either added singly or combined in order to detect multiply-resistant 
bacteria. Incubation was under both aerobic and anaerobic conditions. The plates containing single antibiotics and the control plates did show growth. The numbers of organisms resistant to each of the antibiotics on its own fluctuated widely but the fluctuation bore no discernible relationship to the periods of experimental work by G.R.B. Faeces were monitored from 2 weeks before the first experiment until 1 month after the last. The interval between the collection of specimens varied.

\section{RESULTS}

A total of 44 specimens was received and on only one occasion (one week after the third experiment) was a multiply-resistant $E$. coli isolated. This strain from a single colony was biochemically different from all the experimental strains. On eight occasions Candida albicans was isolated; this organism was detected in specimens collected before, during and after the experimental periods.

\section{DISCUSSION}

The period of monitoring lasted 9 months and 44 samples of faeces were examined; at no time was the plasmid-containing strain $E$. coli $\chi 925 \mathrm{R} 1$ isolated. It seems unlikely that the one multiply-resistant colony which was observed on a single occasion had occurred as a result of plasmid transfer, since this isolation was made one week after the experimenter had handled plasmid-containing cultures, and there was no evidence to suggest that $E$. coli $\chi 925 \mathrm{R} 1$ was in the intestine of the experimenter at any time.

Candida albicans is normally resistant to the antibiotics used in the monitoring and is a eukaryote, so it is unlikely that plasmid transfer occurred.

It must be accepted that this was a limited monitoring as the number of specimens received depended on the experimenter's bowel habits and the selection of samples. On the other hand, the monitoring period covered 9 months and some of the experiments involved 801 cultures of plasmid-containing $E$. coli. It would be foolish to claim that there is no possible hazard to the experimenter, but it would appear that, providing adequate care is taken in performing laboratory techniques, the risk may not be great. However, it should be stressed that such experiments should only be performed using appropriate techniques carried out with meticulous care. It must also be emphasized that these findings relate to one system only and they may not be applicable to other plasmids and other strains of bacteria.

\section{REFERENCES}

ANDERSON, E. S. (1975). Viability of, and transfer of a plasmid from, E. coli $\mathrm{K} 12$ in the human intestine. Nature, London 255, 502-504.
Hartley, C. L., Petrocheilou, V. \& Richmond, M. H. (1976). Antibiotic resistance in laboratory workers. Nature, London 260, 558. 